\title{
Light-Responsive Dynamic Protein Hydrogels Based on LOVTRAP
}

\author{
Tianyu Duan, Qingyuan Bian and Hongbin $\mathrm{Li}^{*}$ \\ Department of Chemistry \\ University of British Columbia \\ Vancouver, BC, V6T 1Z1 \\ Canada
}

\section{Supporting Information}

Full amino acid sequences of all the engineered proteins. The sequence of GB1 is in black, LOV2 in orange, zdk1 in magenta, SpyTag in blue, and SpyCatcher in green. The underlined italic sequence are linkers resulting from the restriction enzyme sequences used in the cloning.

GB1-SpyTag-LOV2 (G-St-LOV2)

MGHHHHHHGSMDTYKLILNGKTLKGETTTEAVDAATAEKVFKQYANDNGVDGEWTY

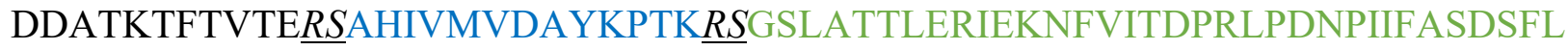
QLTEYSREEILGRNCRFLQ GPETDRATVRKIRDAIDNQTEVTVQLINYTKSGKKFWNLFH LQPMRDQKGDVQYFIGVQLDGTEHVRDAAEREGVMLIKKTAENIDEAAKEL

Zdk1-GB1-SpyTag (zdk1-G-St)

MGHHHHHHGSMVDNKFNKEKTRAGAEIHSLPNLNVEQKFAFIVSLFDDPSQSANLLAE AKKLNDAQAPKR $\underline{R}$ MDTYKLILNGKTLKGETTTEAVDAATAEKVFKQYANDNGVDGEW TYDDATKTFTVTE $\underline{R S A H I V M V D A Y K P T K R S L E ~}$

(GB1-SpyCatcher) 3 [(G-Sc) $)_{3}$ MHHHHHHGSMDTYKLILNGKTLKGETTTEAVDAATAEKVFKQYANDNGVDGEWTYD DATKTFTVTE $\underline{R}$ GAMVDTLSGLSSEQGQSGDMTIEEDSATHIKFSKRDEDGKELAGATM ELRDSSGKTISTWISDGQVKDFYLYPGKYTFVETAAPDGYEVATAITFTVNEQGQVTVN GKATKGDAHI $\underline{R} S$ MDTYKLILNGKTLKGETTTEAVDAATAEKVFKQYANDNGVDGEWT YDDATKTFTVTE $R S G A M V D T L S G L S S E Q G Q S G D M T I E E D S A T H I K F S K R D E D G K E L A G A$ TMELRDSSGKTISTWISDGQVKDFYLYPGKYTFVETAAPDGYEVATAITFTVNEQGQVT VNGKATKGDAHI $\underline{R} \underline{M}$ MTYKLILNGKTLKGETTTEAVDAATAEKVFKQYANDNGVDGE WTYDDATKTFTVTERSGAMVDTLSGLSSEQGQSGDMTIEEDSATHIKFSKRDEDGKELA GATMELRDSSGKTISTWISDGQVKDFYLYPGKYTFVETAAPDGYEVATAITFTVNEQGQ VTVNGKATKGDAHIRS 

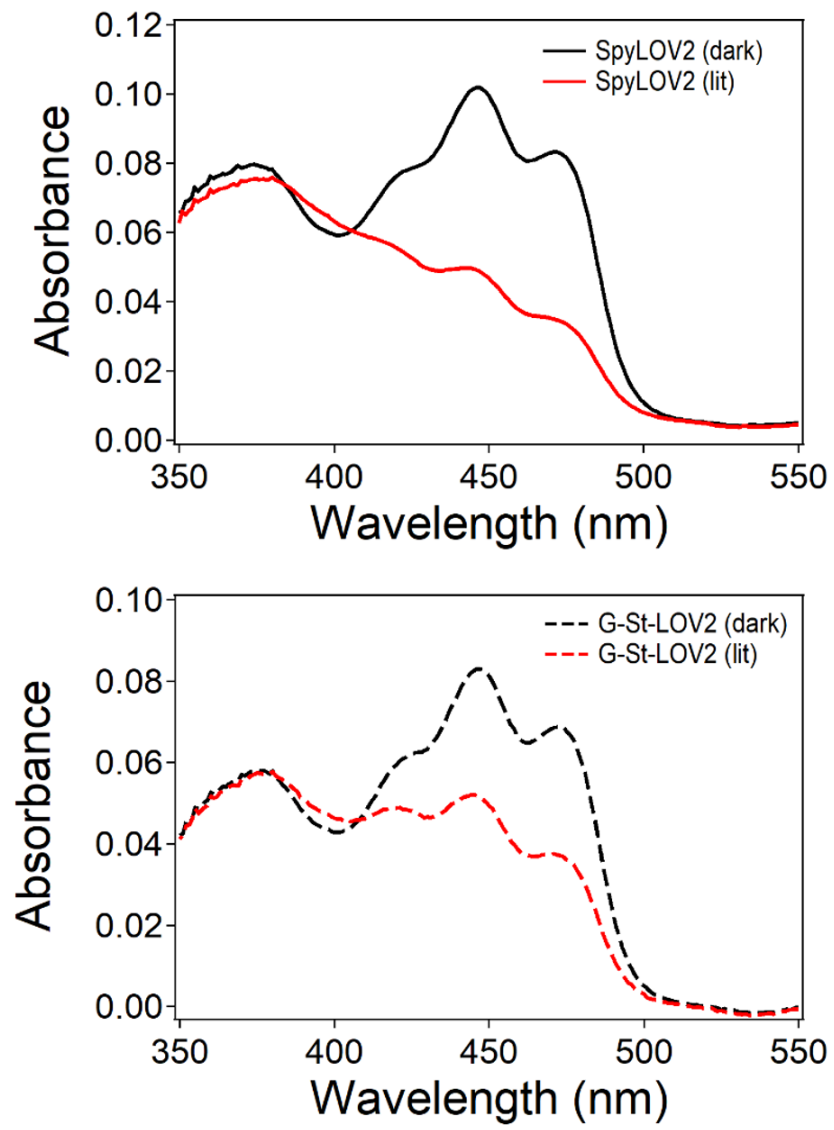

Figure S1. UV-Vis absorbance spectra of SpyLOV2 (Top) and G-St-LOV2 (Bottom). Both sample solutions were first tested under dark condition and subsequently under lit condition. In the dark condition, a sample solution had been kept in dark environment without any blue light irradiation before the test. In the lit condition, a sample solution contained in a quartz cuvette was irradiated by a 470-nm LED light source at $1-\mathrm{cm}$ distance for $1 \mathrm{~min}$. The photobleaching behaviors of both SpyLOV2 and G-St-LOV2 were consistent with the photobleaching behavior of un-fused LOV2. 


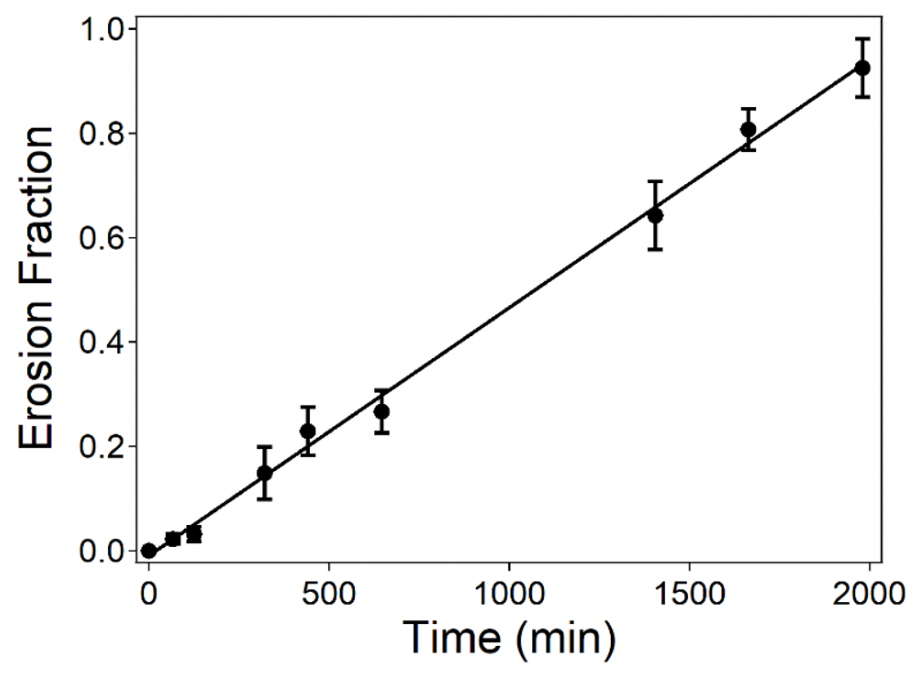

Figure S2. Erosion profile of $100 \mathrm{mg} 12 \%$ LOVTRAP hydrogel with a surface area of $0.865 \mathrm{~cm}^{2}$ at room temperature in $1 \mathrm{x}$ phosphate buffer saline (PBS), $\mathrm{pH} 7.4$. The results were averaged from 3 parallel experiments. The mass loss of the hydrogel showed a linear relationship versus time, indicating that its erosion occurred at the surface. A linear regression (solid line) measures an erosion rate of $6.60 \times 10^{-3} \mathrm{mg} \cdot \mathrm{cm}^{-2} \cdot \mathrm{min}^{-1}$. 